\title{
Barotrauma induced tracheal diverticulum rupture: imaging findings
}

\author{
Cathal N O'Leary, ${ }^{1}$ James W Ryan, ${ }^{2}$ Gillian Corbett, ${ }^{1}$ Carole A Ridge ${ }^{2}$
}

${ }^{1}$ Mater Misericordiae University Hospital, Dublin, Ireland 2Department of Radiology, Mater Misericordiae University Hospital, Dublin, Ireland

\section{Correspondence to} Dr James W Ryan, jamesryannchd@gmail.com

Accepted 7 September 2016

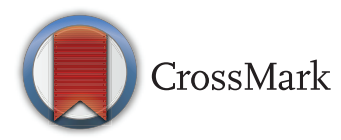

To cite: O'Leary $C N$ Ryan JW, Corbett G, et al. BMJ Case Rep Published online: [please include Day Month Year] doi:10.1136/ bcr-2016-217518

\section{DESCRIPTION}

An elderly patient was admitted for a coronary artery bypass graft. The postoperative course was complicated by decompensated atrial fibrillation requiring repeat endotracheal intubation.

On examination subcutaneous emphysema was noted, which progressed to involve the upper arms, cervical region and face.

Chest X-ray and CT scan demonstrated subcutaneous emphysema and pneumomediastinum (figures 1 and 2). Fibre optic bronchoscopy revealed a normal tracheobronchial tree, without obvious orifices in the tracheal wall. A CT scan of the thorax revealed a tracheal diverticulum on the right posterolateral aspect of the trachea (figures 3-5). A defect in the superoanterior wall of the diverticulum was identified as the site of rupture. Rupture was likely secondary to postintubation barotrauma. Given the absence

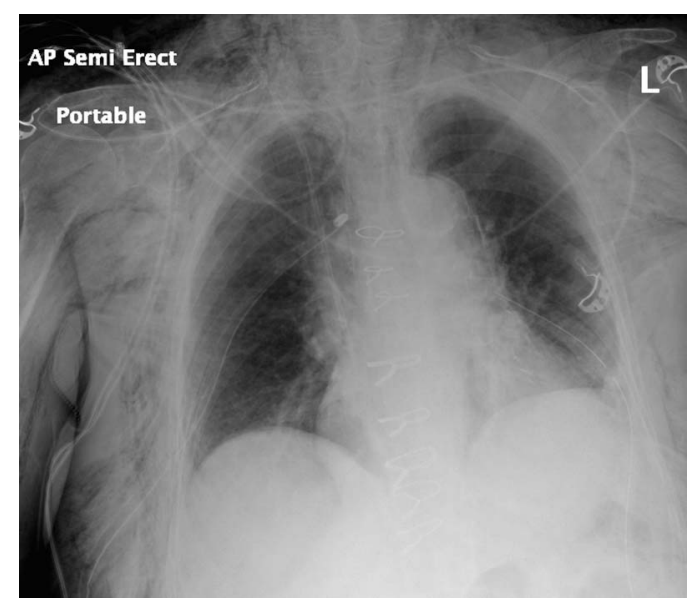

Figure 1 Chest X-ray: pneumomediastinum, diffuse subcutaneous emphysema, visible pectoralis major striations.

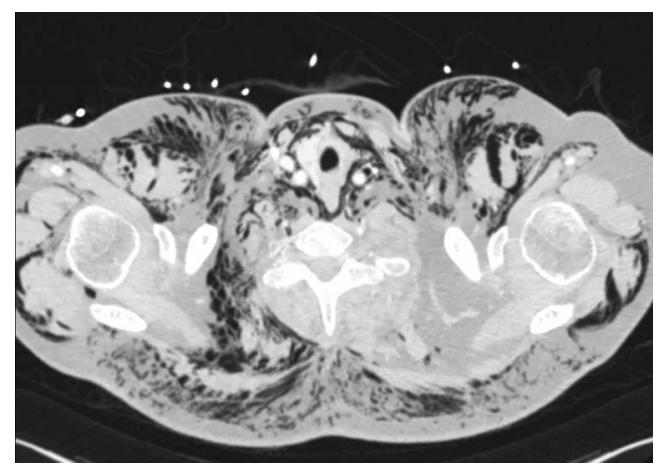

Figure 2 Axial CT scan of lung windows: pronounced subcutaneous emphysema of the upper chest wall.

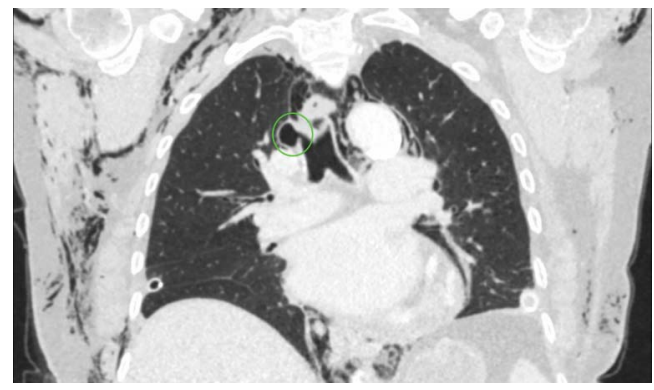

Figure 3 Coronal CT scan of lung windows: tracheal diverticulum arising from the right lateral aspect of the distal trachea.

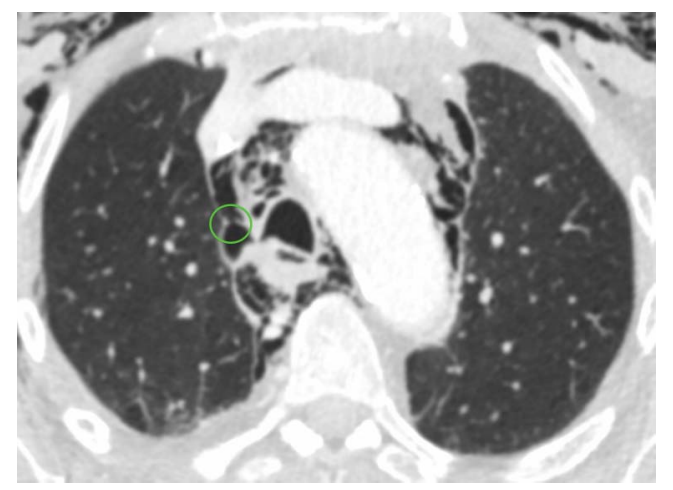

Figure 4 Axial CT scan of lung windows: there is a defect in the anterior wall of the diverticulum at the site of rupture.

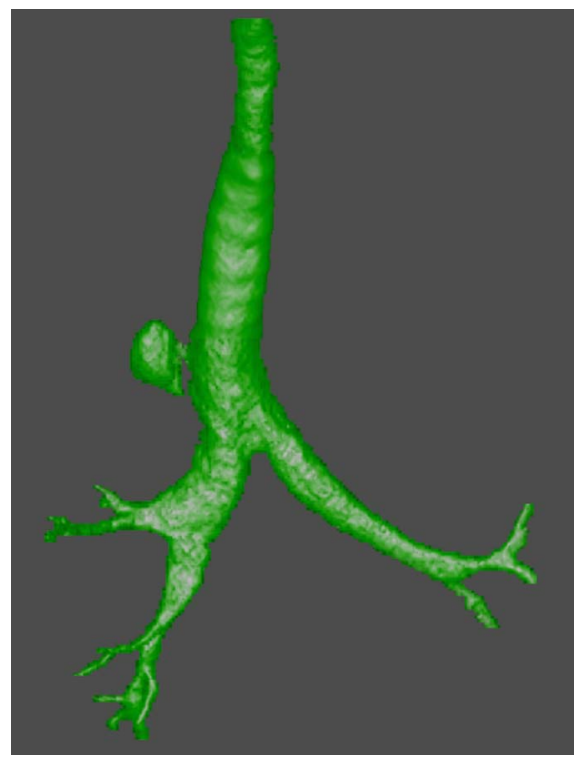

Figure 5 Three-dimensional reconstruction of trachea: diverticulum arising from distal third of trachea on the right. 
of airway compromise or respiratory failure, the decision was made to treat conservatively.

Tracheal diverticula are invaginations of the tracheal wall found in $1 \%$ of the population. ${ }^{1}$ Tracheal diverticula may be congenital or acquired. Acquired diverticula are lined by mucosa alone, congenital diverticula are lined by mucosa, smooth muscle and cartilage. They are predominantly found on the

\section{Learning points}

- Tracheal diverticula are uncommon but important differentials of tracheobronchial rupture.

- Thin slice $(1 \mathrm{~mm})$ CT scan with three-dimensional reconstruction is helpful in the diagnosis of tracheal diverticula and in identifying the site of rupture.

- Cases of pronounced surgical emphysema can be treated conservatively if there is no coexisting airway compromise or pneumothorax. Surgery is reserved for younger patients with symptomatic, congenital diverticula. right posterolateral aspect of the trachea due to a deficiency of cartilage and absence of the oesophagus supporting the paratracheal tissue at this level. ${ }^{2}$ They are most commonly asymptomatic, though they can act as reservoirs for infection or have mass effect. They are an uncommon cause of tracheobronchial rupture. $^{2} 3$ The patient's symptoms improved with conservative management. She was discharged 2 weeks postoperatively with minimal residual subcutaneous emphysema.

Twitter Follow Cathal O'Leary at @leery_cathal

Contributors CNO is the primary author. JWR procured and selected images. GC contributed to literature review. CAR is the senior author and advisor.

Competing interests None declared.

Patient consent Not obtained.

Provenance and peer review Not commissioned; externally peer reviewed.

\section{REFERENCES}

1 Soto-Hurtado EJ, Peñuela-Ruíz L, Rivera-Sánchez I, et al. Tracheal diverticulum: a review of the literature. Lung 2006;184:303-7.

2 Chauhan G, Nayar P, Diwan S, et al. Paratracheal cyst rupture: a false alarm for tracheal rupture. J Anaesthesiol Clin Pharmacol 2013;29:276-8.

3 Marques J, Henriques AR, Azevedo L, et al. Paratracheal cyst rupture: a differential diagnosis for tracheal rupture. Brazilian J Anesthesiol (English Ed) 2014;118; doi:10.1016/j.bjane.2014.07.014.

Copyright 2016 BMJ Publishing Group. All rights reserved. For permission to reuse any of this content visit

http://group.bmj.com/group/rights-licensing/permissions.

BMJ Case Report Fellows may re-use this article for personal use and teaching without any further permission.

Become a Fellow of BMJ Case Reports today and you can:

- Submit as many cases as you like

- Enjoy fast sympathetic peer review and rapid publication of accepted articles

- Access all the published articles

- Re-use any of the published material for personal use and teaching without further permission

For information on Institutional Fellowships contact consortiasales@bmjgroup.com

Visit casereports.bmj.com for more articles like this and to become a Fellow 